\title{
Knowledge, Attitude and Perception About Sustainable Developmental Goals (SDGs) Among Clinical Medical Students of Bingham University Teaching Hospital, Jos
}

\author{
Maryam Shehu ${ }^{1,}$,, Hassan Shehu ${ }^{2}$ \\ ${ }^{1}$ Department of Paediatrics, Bingham University Teaching Hospital, Jos, Nigeria \\ ${ }^{2}$ Department of Surgery, Bingham University Teaching Hospital, Jos, Nigeria
}

Email address:

maryamshehu1405@gmail.com (M. Shehu)

${ }^{*}$ Corresponding author

\section{To cite this article:}

Maryam Shehu, Hassan Shehu. Awareness, Knowledge, Attitude and Perception About Sustainable Developmental Goals (SDGs) Among Clinical Medical Students of Bingham University Teaching Hospital, Jos. Journal of Health and Environmental Research.

Vol. 4, No. 4, 2018, pp. 130-134. doi: 10.11648/j.jher.20180404.12

Received: September 20, 2018; Accepted: September 29, 2018; Published: October 27, 2018

\begin{abstract}
Background: The Sustainable Development Goals (SDGs) is the successor to the Millennium Development Goals (MDGs). The program was started in 2015 and is expected to end in 2030. Objective: The aim of the study was to determine the awareness, knowledge, attitude and perception of SDGs among clinical medical students of Bingham University Teaching Hospital, Jos. Method: Consecutive sampling method was used. Results: A total of $141(82.46 \%)$ were aware of SDGs while $30(17.46 \%)$ have not heard about SDGs; $140(81.87 \%)$ got the full meaning of SDGs correctly, $3(1.75 \%)$ were wrong, while $28(16.37 \%)$ did not know its meaning. The major sources of information about SDGs from 203 multiple responses were from the internet with $84(41.35 \%)$ and Television 34 (16.75\%). The least were from conferences with $3(1.48 \%)$. The level of knowledge about the SDGs was generally very poor, with only $26(15.20 \%), 13(7.60 \%)$ and $1(0.58 \%)$ knowing the correct number of goals, targets, and indicators respectively. The percentage knowledge on the year it was launched, for how long it is supposed to last and the year it will end were also poor with $29(16.96 \%), 30(17.54 \%)$ and $35(20.47 \%)$ respectively. The knowledge on the academia playing a more prominent role in the SDGs than MDGs was the highest with 60 (35.09\%); getting it correctly, followed by the knowledge on there are more goals on inequality in the SDGs than the MDGs with 46 (26.90\%). The student's perception on the impact of SDGs most likely going to be better than MDGs was $100(58.48 \%)$. The level of awareness of SDGs in Nigeria was perceived to be poor by $126(73.68 \%)$ and good by $45(26.32 \%)$. Only 48 (28.07\%) of the students agreed that government is committed to seeing the fulfillment of the SDGs, while $123(71.92 \%)$ did not agree that the government is committed. The attitude of the students towards learning about the SDGs was good as $123(71.93 \%)$ agreed that SDGs should be taught in Universities, while 48 (28.07\%) did not agree that SDGs should be taught in Universities. Only 35 $(20.47 \%)$ of the students did not want to study about SDGs. Conclusion: There will be need to teach university students about SDGs, so as to improve their knowledge of the ongoing SDGs.
\end{abstract}

Keywords: Knowledge, SDGs, Clinical, Medical, Students, Jos

\section{Introduction}

The Sustainable Development Goals (SDGs) is the successor to the Millennium Development Goals (MDGs). The program was started in 2015, to end in 2030, hence the name Agenda 2030; the year which the SDGs should have been attained globally The SDGs have a broader agenda than the MDGs, with 17 goals, 169 targets, and well over 200 indicators The SDGs involve a five "Ps" (people, prosperity, planet, peace, and partnership) agenda; and these five "Ps" are for all countries and people of the world [3].

The SDGs are a set of priorities and aspirations to guide all countries in tackling the world's most pressing challenges, including ending poverty and hunger; protecting the planet from, degradation and addressing climate change; ensuring that all people can enjoy prosperous, healthy and fulfilling 
lives; and fostering peaceful, just and inclusive societies free from fear and violence The SDGs is to continue the work of the Millennium Development Goals (MDGs), which drove global action to address the basic needs of the world's poorest countries from 2000 to 2015 .

However, the SDGs differ from the MDGs in several significant ways that make them far more influential and consequential than the MDGs. The SDGs cover a much broader range of challenges than the MDGs. They emphasis the interlinkages between the social, economic, and environmental dimensions of sustainable development, as well as between the goals themselves. They include targets devoted to mobilizing the means required to implement the SDGs, such as partnerships, financing and enabling policies. They recognize that addressing the challenges of the SDGs is everybody's responsibility and explicitly call on business, civil society, and the tertiary and academic sectors among others to collaborate on the achievement of the SDGs [5].

The achievement of the SDGs will also hinge on first the awareness and knowledge of the SDGs, just as was said by Nashash et al on the MDGs: For MDGs to be achieved " grassroots is required before demand, where people must first be aware of the MDGs and work with them to demand their fulfillment from their governments" The Nigerian government started a more proactive way of educating and implementing the MDGs when the president set up an office for special assistant to the presidency on MDGs in 2005 Nigeria began to find its rhythm in the implementation of the MDGs from 2005 when it successfully negotiated a debt relief from the Paris Club which enabled it to increase and target public investments in pro-poor interventions aimed at achieving the MDGs It can therefore be said that Nigeria had a slow start to MDGs which is one of the major reasons why its achievements were limited. Akinlolu O. G et al in their study on the awareness and knowledge on SDGs in a University Community in Southwestern Nigeria found only $43 \%$ of the respondents aware of the SDGs and only $4.2 \%$ had good knowledge of the SDGs. However, 56.3\% have positive attitude towards it. Another article by Ejechi Victor [9], from the University of Benin on the awareness and perception of Sustainable Development Goals (SDGs), among, library personnel in Edo State University Library, found $41(34.7 \%)$ aware of Sustainable Development Goals (SDGs) while $59(50 \%)$ agreed to know what Sustainable Development Goals (SDGs) is all about, although only 47 $(39.8 \%)$ of the $59(50 \%)$ proved their knowledge on the number of goals by strongly disagreeing that the SDGs are eight goals given by the United Nations. The level of awareness was similar compared to that gotten by Akinlolu et al [8], however the level of knowledge seems to be higher in the study done by Ejechi Victor [9], compared to Akinlolu et al, a plausible explanation could be because of the difference in the tool used to access their knowledge, the difference in the category of staff interviewed and the time difference between their studies.

Education has a transformational role to play in addressing the development challenges that the world faces today and over the next 15 years in achieving the SDGs. It plays a foundational role that focuses on improving life opportunities and outcomes for the most marginalized in society [10-11]. Education directly contributes to the goals of addressing poverty reduction and reduced inequalities, health and nutrition, economic growth and labor market opportunities, as well as peace building and the promotion of democratic institutions [10-11].

Sustainable development starts with safe, healthy, and well-educated children The SDGs embrace an expanded vision of skills with all actors, like the media raising awareness through community and social media, the possibility for civil society to engage concretely in delivering education. Retired teachers and educated members of the community to volunteer in conducting classes, dispensing adult literacy or functional literacy classes The higher educational Centre's should contribute their quota through research, innovations, skills and knowledge acquisition of the highest and best quality with subsequent dissemination of such skills and knowledge for the advancement of the society. Quality education has been defined as ensuring inclusive and equitable quality education and promoting lifelong learning opportunities for all Education is a fundamental human enabling right that is for the public good. The 2030 agenda places education at the Center of the realization of many of the other sustainable developmental goals [15].

Nigeria's future transformation depends to a large extent not only on its capacity to provide compulsory and inclusive quality basic education [16], but in also including universities which are higher educational institutions often regarded as the Ivory Towers of learning [8], to contribute in the achievements of the SDGs by higher rates of innovation, which will translate into higher overall productivity and faster introduction of new technology. Additionally, its impact will be reflected on economic growth The tertiary education and scientific research sectors are explicitly recognized in a number of the SDGs. The SDG agenda covers a wide range of interconnected social, economic, and environmental challenges and the unique functions and expertise of universities are critical for overcoming all of these [4, 17]. Given the size of the task of achieving the SDGs, and the critical roles universities have to play in delivering on the SDGs, there is an urgent need for the sector to accelerate action. There is the need to create awareness and impact knowledge in the university sector, so they can contribute their quota to the achievement of these goals.

\section{Methods and Materials}

The study was a cross-sectional descriptive study. A selfdesigned semi-structured questionnaire was administered to the students who fulfilled the criteria and consented to the study. The sampling method was consecutive sampling of all the students until sample size was obtained. The proposal for the study was approved by the Ethical Committee of the Teaching Hospital. A total of 173 questionnaires were administered but 2 of them were not properly filled, so a total 
of 171 questionnaires were analyzed. The data was entered into SPSS statistical package version 20 and analyzed. Frequency tables and charts were drawn to show the awareness, knowledge, and perception of the students.

\section{Results}

One hundred and seventy-one students were enrolled into the study. There were 102 (59.60\%) females and $69(40.35 \%)$ males with $\mathrm{M}$ : F ratio of $1: 1.48$. A total of $141(82.46 \%)$ were aware of SDGs while $30(17.46 \%)$ have not heard about SDGs.

Table 1. Distribution of have you heard of SDGs by sex.

\begin{tabular}{llll}
\hline $\begin{array}{l}\text { Have you heard } \\
\text { of SDGs }\end{array}$ & Female & Male & \multirow{2}{*}{ Total (\%) } \\
\cline { 2 - 3 } & Frequency (\%) & Frequency (\%) & \\
\hline Yes & $81(57.45 \%)$ & $60(42.55 \%)$ & $141(82.46 \%)$ \\
No & $21(70.0 \%)$ & $9(30.0 \%)$ & $30(17.545)$ \\
Total & $102(59.65 \%)$ & $69(40.35 \%)$ & $171(100.0 \%)$ \\
\hline
\end{tabular}

One hundred and forty (81.87\%) got the full meaning of SDGs correctly, 3 (1.75\%) were wrong, while 28 (16.37\%) did not know the meaning.

Table 2. What is the full meaning of SDGs.

\begin{tabular}{llll}
\hline Meaning of SDGs & Correct (\%) & Wrong (\%) & I don't know (\%) \\
\hline Yes & $140(81.87)$ & $1(0.58)$ & $28(16.37)$ \\
No & $31(18.13)$ & $170(99.42)$ & $143(83.36)$ \\
Total & $171(100.0)$ & $171(100.0)$ & $171(100.0)$ \\
\hline
\end{tabular}

The major sources of information about SDGs from 203 multiple responses were from the internet with $84(41.35 \%)$ and Television 34 (16.75\%). The least were from conferences with $3(1.48 \%)$.

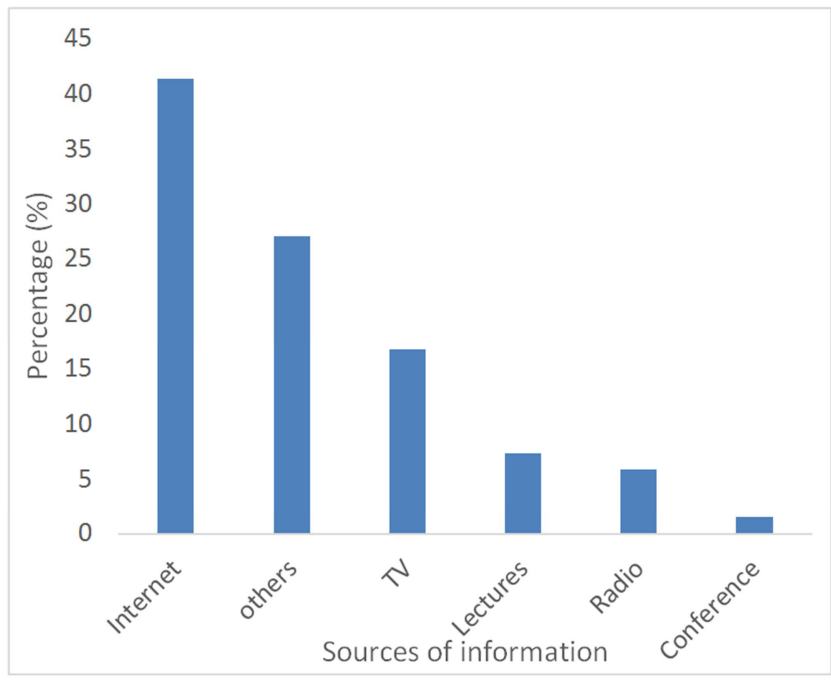

Figure 1. Sources of information.

The knowledge about the SDGs was generally very poor, with only $26(15.20 \%), 13(7.60 \%)$, and $1(0.58 \%)$ knowing the correct number of goals, targets and indicators. The percentage knowledge on the year it was launched, for how long it is supposed to last and the year it will end were also poor with $29(16.96 \%), 30(17.54 \%)$ and $35(20.47 \%)$ respectively. The knowledge on the academia playing a more prominent role in the SDGs than MDGs was the highest with $60(35.09 \%)$ getting it correctly, followed by the knowledge on there are more goals on inequality in the SDGs than the MDGs with 46 (26.90\%).

Table 3. Knowledge about SDGs.

\begin{tabular}{llll}
\hline Knowledge about SDGs & Correct (\%) & Wrong (\%) & Don't know (\%) \\
\hline How many goals & $26(15.20)$ & $11(6.43)$ & $134(78.36)$ \\
How many targets & $13(7.60)$ & $5(2.92)$ & $153(89.47)$ \\
How many indicators & $1(0.58)$ & $5(2.92)$ & $165(96.490$ \\
The year it was launched & $29(16.96)$ & $26(15.20)$ & $116(67.84)$ \\
How long it lasted & $30(17.54)$ & $10(5.85)$ & $131(17.61)$ \\
The year it ended & $35(20.47)$ & $13(7.60)$ & $123(71.93)$ \\
How many countries signed treaty & $3(1.75)$ & $11(6.43)$ & $157(91.81)$ \\
How many goals on health & $2(1.17)$ & $29(16.96)$ & $140(81.87)$ \\
There more goals on health than environment & $13(7.60)$ & $36(21.05)$ & $122(71.33)$ \\
There are more goals on development than on health & $34(19.88)$ & $13(7.60)$ & $124(74.27)$ \\
There is more room for the academia to contribute in SDGs & $60(35.09)$ & $8(4.68)$ & $103(60.23)$ \\
There are more goals on inequality in SDGs than MDGs & $46(26.90)$ & $7(4.07)$ & $118(67.01)$ \\
\hline
\end{tabular}

The student's perception on the impact of SDGs most likely going to be better than MDGs was 100 (58.48\%), while 71 $(47.52 \%)$ did not agree that the impact of SDGs was likely going to be better than the MDGs.

Table 4. The Impact of SDGs will be more than MDGs.

\begin{tabular}{ll}
\hline Impact of SDGs more than MDGs & Frequency (\%) \\
\hline Yes & $100(58.48)$ \\
No & $71(41.52)$ \\
Total & $171(100.0)$ \\
\hline
\end{tabular}

The level of awareness of SDGs in Nigeria was perceived to be poor by $126(73.68 \%)$ and good by $45(26.32 \%)$. 
Table 5. The level of awareness of SDGs among Nigerians.

\begin{tabular}{lllll}
\hline Awareness of SDGs is good among igerians & Agree (\%) & Strongly agree (\%) & Disagree (\%) & Strongly Disagree (\%) \\
\hline Yes & $36(21.05)$ & $9(5.26)$ & $28(16.37)$ & $98(57.31)$ \\
No & $135(78.95)$ & $162(94.74)$ & $143(83.63)$ & $73(42.69)$ \\
Total & $171(100.0)$ & $171(100.0)$ & $171(100.0)$ & $171(100.0)$ \\
\hline
\end{tabular}

Only $48(28.07 \%)$ of the students agreed that the government is committed to see the fulfillment of the SDGs, while 123 $(71.92 \%)$ did not agree that the government is committed.

Table 6. The Government is committed to the fulfillment of SDGs.

\begin{tabular}{llll}
\hline The Government is committed to SDGs & Agree (\%) & Strongly Agree (\%) & Disagree (\%) \\
\hline Yes & $42(24.56)$ & $6(3.51)$ & $100(58.48)$ \\
No & $129(79.44)$ & $165(96.49)$ & $71(41.52)$ \\
Total & $171(100.0)$ & $171(100.0)$ & $171(100.0)$ \\
\hline
\end{tabular}

The attitude of the students towards learning about the SDGs was good, as $123(71.93 \%)$ agreed that SDGs should be taught in the Universities while $48(28.07 \%)$ did not agree that SDGs should be taught in the Universities.

Table 7. SDGs should be taught in Universities.

\begin{tabular}{llll}
\hline SDGs should be taught in Universities & Agree (\%) & Strongly Agree (\%) & Disagree (\%) \\
\hline Yes & $84(49.12)$ & $39(22.81)$ & $36(21.05)$ \\
No & $87(50.88)$ & $132(77.19)$ & $135(78.95)$ \\
Total & $171(100.0)$ & $171(100.0)$ & $171(100.0)$ \\
\hline
\end{tabular}

Only $35(20.47 \%)$ of the students did not want to study about the SDGs, while $136(79.53 \%)$ are willing to study about the SDGs.

Table 8. I am willing to study about the SDGs.

\begin{tabular}{ll}
\hline Willing to study about the SDGs & Frequency (\%) \\
\hline Yes & $136(79.53)$ \\
No & $35(20.47)$ \\
Total & $00.0)$ \\
\hline
\end{tabular}

\section{Discussion}

The awareness about SDGs was good, with a little over $80 \%$ of the students being aware of it. This however falls short of the SDGs development agenda to ensure that no one is left behind This is especially important because the educational sector is said to be the foundation and the center of the SDGs $[10,14,19]$. The level of awareness from this study is higher than what Akinlolu O. G et al and Ejechi Victor got in their studies in Osun and Edo states respectively. A plausible explanation could be because of the difference in the timing, and the fact that the studies by Akinlolu O. G et al and Ejechi Victor included both Academic and non-academic staff. The major source of information was from the internet, this could be because they do not have lecture topics on SDGs and therefore most of the students got their information via the internet since they have access to the internet through their smartphones. The knowledge about the number of goals, the year it was launched and how long it is supposed to last was poor. They also have a very poor knowledge about the number of goals on health, targets, and indicators. The reason could be because most of the knowledge they got were from the internet and they might not have paid particular attention to the details. It's possible they would have known better if they were taught in class. This is comparable to the results gotten by Akinlolu O.
$\mathrm{G}$ et al in their studies where only $4.2 \%$ had good knowledge about the SDGs. There is a great disparity between the awareness and the knowledge about the SDGs, this supports the claim of the survey done by OECD that awareness does not necessarily translate into knowledge The Survey showed that about $60-65 \%$ of people did not know about the SDGs at all in the United States of America (USA) and the United Kingdom (UK), as against $20-25 \%$ in France and Germany. Furthermore, less than $5 \%$ of people in the USA and UK have fair knowledge about the SDGs while about $20 \%$ of the people in France and Germany have fair knowledge about the SDGs The perception of the students on the impact of SDGs in Nigeria was good, as $58 \%$ of them agree that the impact of the SDGs will be more than the MDGs. The awareness of SDGs generally among Nigerians was believed to be fair, with $45 \%$ agreeing that the awareness is good. This could further be explained by the results which showed that only $48 \%$ of the students believed that the government was committed to the fulfillment of the SDGs agenda. The results are similar to the results gotten by Akinlolu $\mathrm{O}$ et al with $56 \%$ of the respondents having positive attitude towards the fulfillment of the SDGs. The attitude of the students towards learning about the SDGs was good, as about $80 \%$ of them were willing to study about it. Over $70 \%$ of the students were also of the opinion that it should be taught in the universities.

\section{Conclusion}

The awareness about SDGs among Bingham University Clinical students was good; however, this did not translate to good knowledge about the SDGs. Their attitude towards the knowledge of SDGs was also good. The perception on the awareness and the impact of SDGs in Nigeria was fair. There is therefore the need to teach students about the SDGs so as 
to improve their knowledge and help them understand their roles in the fulfillment of the ongoing SDGs.

\section{References}

[1] Transforming our World: The 2030 Agenda for Sustainable Development | UNFPA - United Nations Population Fund [Internet]. [cited 2018 Aug 22]. Available from: https://www. unfpa. org/resources/transforming-our-world-2030-agendasustainable-development

[2] IAEG-SDGs - SDG Indicators [Internet]. [cited 2018 Aug 22]. Available from: https://unstats.un.org/sdgs/iaegsdgs/metadata-compilation/

[3] Sustainable Development Goals | UNDP in Nigeria [Internet]. [cited 2018 Aug 22]. Available from: http://www.ng.undp.org/content/nigeria/en/home/sustainabledevelopment-goals.html

[4] SDSN Australia/Pacific. Getting Started With the SDGs in Universities: A Guide for Universities, Higher Education Institutions, and the Academic Sector. Aust New Zeal Pacific Ed [Internet]. 2017; 55. Available from: http://apunsdsn.org/wp-content/uploads/2017/08/University-SDGGuide_web.pdf

[5] Nilsson M, Griggs D, Visbeck M. Policy: Map the interactions between Sustainable Development Goals. Nature [Internet]. 2016 Jun 15 [cited 2018 Aug 22]; 534 (7607): 320-2. Available from: http://www.nature.com/doifinder/10.1038/534320a

[6] Nashash HM. LEVEL OF MILLENNIUM DEVELOPMENT GOALS AWARENESS AMONG STUDENTS AT PRINCESS ALIA UNIVERSITY COLLEGE. Eur Sci J [Internet]. 2013 [cited 2018 May 12]; 9 (16): 1857-7881. Available from:

https://eujournal.org/index.php/esj/article/viewFile/1134/1150

[7] Nigeria 2015 Millennium Development Goals End-Point Report ABRIDGED VERSION [Internet]. [cited 2018 Sep 3]. Available from: www.mdgs.gov.ng

[8] Akinlolu OG, Grace BM, Damilola BP, Esther A-OO. Awareness and Knowledge of the Sustainable ... Awareness and Knowledge of the Sustainable Development Goals in a University Community in Southwestern Nigeria. Ethiop J Heal Sci [Internet]. 2017 [cited 2018 May 12]; 27 (6). Available from: http://dx.doi.org/10.4314/ejhs.v27i6.12

[9] Ejechi V, Ejechi VT. Awareness And Perception of Sustainable Development Goals (SDGs), among, Library Personnel in Edo state University Library Information Literacy Skills: A neccesity for Nigerians View project Awareness And Perception of Sustainable Development Goals (SDGs) [Internet]. Available from: https://www.researchgate.net/publication/323391987

[10] EDUCATION AND THE SDGs [Internet]. 2016 [cited 2018 Aug 14]. Available from: https://educationaboveall.org/uploads/library/file/2a8e15847d. pdf

[11] Education for Sustainable Development Goals Learning Objectives [Internet]. 2017 [cited 2018 Aug 22]. Available from:

http://unesdoc.unesco.org/images/0024/002474/247444e.pdf

[12] Lake --Anthony. SUSTAINABLE DEVELOPMENT STARTS WITH SAFE, HEALTHY AND WELLEDUCATED CHILDREN [Internet]. 2013 [cited 2018 Sep 4]. Available from: http://www.unicef.org/parmo/files/Post_2015_UNICEF_Key_ Messages.pdf

[13] UNESCO Meeting Report. 8th Collective Consultation of NGOs (CCNGOs) Education 2030 [Internet]. [cited 2018 Sep 4]. Available from:

http://www.worldomep.org/file/Final_CCNGO_8th_Global_ Meeting_Report.pdf

[14] Unpacking Sustainable Development Goal 4 Education 2030 Sustainable Development Goals United Nations Educational, Scientific and Cultural Organization GUIDE [Internet]. [cited 2018 Sep 4]. Available from: http://unesdoc.unesco.org/images/0024/002463/246300E.pdf

[15] Webb S, Holford J, Hodge S, Milana M, Waller R. International Journal of Lifelong Education Lifelong learning for quality education: exploring the neglected aspect of sustainable development goal 4. 2017 [cited 2018 Sep 4]; Available from: http://www.tandfonline.com/action/journalInformation?journa lCode $=$ tled 20

[16] Development A, Group B. ASSESSING PROGRESS IN AFRICA TOWARD THE MILLENNIUM DEVELOPMENT GOALS [Internet]. [cited 2018 Aug 22]. Available from: https://www.uneca.org/sites/default/files/PublicationFiles/mdg -2015_eng_16sep_rev2.pdf

[17] What role can African universities play in the SDGs? | World Economic Forum [Internet]. [cited 2018 Aug 14]. Available from: https://www.weforum.org/agenda/2015/09/what-rolecan-african-universities-play-in-the-sdgs/

[18] UNITED NATIONS. The Millennium Development Goals Report 2015 [Internet]. [cited 2018 Aug 22]. Available from: http://www.un.org/millenniumgoals/2015_MDG_Report/pdf/ MDG 2015 rev\%28July 1\%29.pdf

[19] Education 2030: Equity and quality with a lifelong learning perspective | Global Education Monitoring Report [Internet]. [cited 2018 Sep 4]. Available from: https://en.unesco.org/gemreport/education-2030-equity-and-quality-lifelong-learningperspective

[20] OECD Development Communication Network (DevCom). What People Know and Think About the Sustainable Development Goals Selected Findings from Public Opinion Surveys Compiled by the OECD Development Communication Network (DevCom) [Internet]. 2017 [cited 2018 Aug 22]. Available from: www.oecd.org/dev/devcom 